\title{
INTEGRATING TECHNOLOGY IN EFL CLASSROOM FOR INDONESIAN ADOLESECENT LEARNERS
}

\author{
Murah Harfani Batubara \\ State Islamic University of North Sumatera, Medan, Indonesia \\ E-mail: murahharfanibatubara@uinsu.ac.id
}

Received: 2021-11-05

Accepted: 2021-12-03

\begin{abstract}
The coming of the internet and the advancement of technology make revolution in Language Pedagogy, especially in the EFL classroom. Teaching the students who were born as the digital natives forces EFL, teachers have to integrate technology in language teaching. This article was written based on a recent EFL teacher's practice. This study employed a case study method with 30 students of grade 9 of Junior High School in the west part of Indonesia as the participants. The aim of this study was to elaborate the way how the teacher made the students more familiar with the computer and the internet access in EFL Classroom. A Messenger Group as the main communication platform, supported by other web-based platforms including school's Facebook (FB) group and online materials were integrated into learning activities. The findings showed that students found using technology in the classroom was easy due to the teacher's instruction. They also reported that the technology integration in their EFL classroom encouraged their creativity and helped to accommodate their diverse interest. As a result, the students feel more comfortable and confident using technology for educational purposes and, become more creative and innovative in doing their project. Beside the clear instructions from the teacher, the availability of the computer laboratory, internet access, and students' smartphones really help the success of this course.
\end{abstract}

Keywords: EFL Classroom, ICT, Integrating Technology, Language Pedagogy

\section{Introduction}

Nowadays, technology is very important in our life. The trend of using Information and Communication Technology (ICT) affects almost all areas of life. The currently implemented curriculum in Indonesia, The 2013 Curriculum recommended the integration of ICT as a critical component in all subjects including English (Al-Munawwarah, 2014). Integrating ICT in each subject in an education curriculum is aimed to assist the students to get high quality in English teaching and learning. The enhancement of ICT and language teaching approach makes a learning environment more meaningful and attractive. Junaidia, et.al (2020) states that the utilization of ICT as source of learning in the EFL classroom becomes one smart step in teaching in the modern era. However, making the students more familiar with technology utilization for educational purposes becomes a challenge for all teachers and English as a foreign language (EFL) teachers are no exception.

Within English language teaching and learning context, the huge transformation has been done in EFL classroom through the growing of technology. As Chen and Hsu (2020) 
state that the advancement of computer and multimedia have modified the way in teaching language. Technology and internet access not only support the teaching learning activity in the classroom but also outside the classroom. Digitalization makes everything become easier in education and give different experiences for EFL learners. Furthermore, through the computer and mobile devices connected to the internet, language learners get access to diverse learning resources within the global context. They could also merge themselves in a real-world experience in terms of joining the target language speaking community. Therefore, EFL learners can develop the ability especially in English skill, appreciate and accept diversity in English, and broaden their perspective and knowledge. (Yang \& Chen, 2007)

In relation to this, how the advancement of technology influences the pedagogical approach in language teaching and learning has become an interesting issue to be studied in the past decades. A myriad of studies focusing on the integration of technology in language learning has been conducted in various classes of language skills such as vocabulary learning and writing workshop. Some studies evaluate the types of technology used such as the utilization of desktop and mobile devices in EFL classes. While some others focus on the quantitative enhancement of technology utilization in EFL teaching learning through experiments in the scheme of experiment and control groups (Supriadi et al., 2020).

Many studies related to the merits of technology integration in the EFL classrooms have also been done. Some find that that using technology in the EFL Classroom can improve language acquisition and motivation (Azmi, 2017). Some others show that both teachers and students have positive attitude and are motivated in teaching and learning process (Azmi, 2017). Bahaus et.al (2011) claim that applying recent strategies will help the students to adopt positive attitude and increase the students' motivation in learning. Similar to this, Nim Park \& Son (2009) state that using Computer Assisted Language Learning in EFL classroom showed that the teachers had positive and favorable attitude and enhanced the way of teaching and learning experiences.

However, despite a plethora of studies that had been conducted in regard to the integration of technology in EFL classrooms, very few focuses on how to familiarize technology in EFL teaching and learning so it could decrease students' reluctance to use English. In sequence to get these aims, the writer decided to combine a set of web-based tools into EFL classroom interaction.

\section{Literature Review}

Technology based e-learning becomes more popular in the context of modern innovative education. With the help of internet access and other technology devices, not only can it help develop learning materials but also make the process of teaching learning easier to do since the innovative concept replaces the traditional approach to the digital EFL classroom (Alfred, 2003).

Nevertheless, the innovative education becomes the main objective of a modern education to prepare the students with the special skills in technology, so they can be competitive with others in the labor market world (Mariani et al., 2019). This is particularly important because in reality the modern education system has not fulfilled the requirements in the labor market yet (Fadel, Charles, Bialik, Maya, Trilling, 2015)

Teachers, as the frontlines in the educational sector, play an important role to introduce ICT in their instructional practices. For EFL teachers, they need to design class activities integrated with technology. Therefore, the clear instructions from the teachers are really 
crucial in making the process of teaching learning sequence. Thus, training in using ICT for EFL teachers is also essential especially for the teachers who are not used to teaching using IT (Pelgrum et.al., 1993).

\subsection{The Development of Technology Competence}

The main goal of the competence-based education is to prepare professional teachers to use ICT and become the facilitator for EFL learners in the teaching process. The competency-based approach is also dominant to develop the modern teachers' skill. The principal intention of innovative education is to provide qualified skill, someone who has all kinds of abilities, who can compete in the labor market. The purpose of competency-based approach is to enhance competitiveness, and innovation in teaching learning approach and the learning environment (Tokareva et al., 2019).

What is actually technology integration in EFL classroom? Technology integration is also called as curriculum integration that is the combination among the parts of technology such as software and hardware, related with area of curriculum to enhance learning process (Backfisch et. al., 2021). Integrating technology in the EFL classroom needs the extensive training and practical experiences for the successful this course. Mastering skills such as how to operate the computer and the ability of using web applications become the basic need for the EFL teachers. If the teacher doesn't have skill in technology, firstly he/she must follow ICT training. This training is not completely new, but it can decrease the possibility of learning difficulties. Commonly as long as course training, the teachers are free to study all related with the way in operating the computer. This chance is really very important for older teachers, who usually have problem in operating a computer. The literacy in technology course will assist the teacher feel free to use basic computer program that is really important to learn, such as the ability to use Microsoft Word, Microsoft Excel, and also PowerPoint. This course will give the EFL teachers the chance to become more confident in using PC.

Another fundamental urgent capability for the teacher is how to present the material by using interactive media for presentation such as projectors and interactive whiteboards. The use of these devices shows the positive effect on the quality of teachers and workshops due to visualization in presentation. Using the projector in class presentation will help the students easier to understand the steps and the material presented by the teachers.

The most important thing is that the teacher should remember that technology is only a tool to support learning instructional strategies. Teachers need to create and design their own steps to integrate technology to EFL classroom and identify what we want to achieve based on the target of the curriculum then decide what kinds of technology are appropriate to achive the goals.

\subsection{Web based Learning System}

The IEEE Learning Technology Standard Committee defines Web Based Learning System (WBLS) is a learning technology system that uses Web Browsers as the main approach of doing interaction with another learners, in this case the internet is as the main method of communication among its systems with another subsystems (Chen, 2010)

As cited by Chen 2010, Jolliffe, Ritter, \& Stevens, (2001) state that WBL provides some interests to traditional classroom-based learning including: we can apply it anytime and anywhere; that is easier for us to update learning material; it also supports the interaction between the learners and the teachers in some ways it can incorporate multiple media such 
as text, audio, video, graphics and also animation; it helps the learners forming learning communities, therefore the facilitators easily checked the progress of the learners, and it allows for a learner-centered approach that can address the many differences between the learners (Chen, 2010)

Many studies have been done related to WBL and some findings show positive impact of using WBL but contrary with others. Even though some discussions concern about the success of technology based learning, but it was not clearly connected to the measurement and the benefits to an organization. These challenges are certainly valid, there may be ways to learn how to change them become the advantages, and we can reduce the negative impacts.

Cook et.al. (2010) stated in his article he found some several reports related with specific configurations such as 1) Email discussion, 2) Learning management system, 3) multimedia, 3) online discussion, 4) Online resources 5) Power point; product Microsoft, 5) Power point slides; uploading power point slide, 6) Simulation or virtual patient, 7) Shincronous Communication, 8) Tutorial, 9) Video Conferencing.

\section{Research Method}

This study employed a case study of an EFL teacher who planned to integrate the technology into EFL classroom. The student participants of this current research were adolescent learners in the west part of Indonesia studying in the grade 9 of Junior High School. The study focused on the integration of technology in EFL classroom. It was assumed that the integration of the computer and web-based learning systems would encourage students' creativity and innovation in learning English.

The qualitative case study design was used in this study. Yin (2013) states that case study research is the empirical inquiry that investigated a contemporary phenomenon and the context are not clearly evidence. Therefore, in this study the researcher was allowed to make research to particular students to endeavor the case study when they were integrating ICT in the EFL classroom. The participants were the students in the grade 9 of Junior High School in one school in North Sumatera Indonesia. They were about 30 randomly selected to participate. All of them could be classified to have low proficiency in using the computer for EFL learning. In this class the EFL teacher tried to implement and integrate ICT in the EFL Classroom. The integration of ICT web-based tool and non-web-based tool in the EFL classroom was started on $7^{\text {th }}$ of August 2021 until $1^{\text {st }}$ of November 2021. The data were collected by direct observation and open ended and close ended questionnaires that were given to the students via Google form to know their learning experiences in EFL Classroom. Furthermore, the data of this study was examined by using interactive model. After the data were collected, data selection was done by filtering them into the main data and get rid of unnecessary data. Then, the data were analyzed in the form of word description before the conclusion was drawn. Finally, the data were verified to make the primary conclusion to solve the research questions.

\section{Results and Discussion}

\subsection{Technology Integration in the EFL Classroom}

To answer the question related to how technology is integrated in the classroom, the data from observation were used as the main data. Based on the data collected, the teacher and the students used messenger group as the main communication platform to interact with each other. All instructions were sent and introduced on the platform every week. This 
group was formed to facilitate the students and the teacher to communicate and to send the agenda and relevant resources as well as students' products or work. The best products from the students' projects were posted on the school's FB account as a promotion to the public about the students' activities and projects.

Although the instructions and agenda were sent in the messenger group the students did their practice in computer laboratory. There were about 40 computers connected to the internet system that could be used by the students. All of the students' activities on the computer were connected to the computer server, so it would be easier for the teacher to control all the students' activities.

For each topic given to the students, the teacher always accompanied them during the learning process. After the end of every meeting, the students needed to submit their work to the messenger group. In addition, they were asked to produce additional work at home using either a desktop of a mobile device. Most of their activities were completed in the computer laboratory. Students who seemed to have more learning motivation completed all or the biggest parts of the required tasks during the class meeting, while other students needed more additional meeting to finish the required tasks during the class time or had to work at home. Timely assistance from the instructor and classmates were available during the class time and or online. Table 1 detailed the learning processes in every meeting, while Figure 1 shows some of the artefacts from the teaching and learning process.

\begin{tabular}{|l|l|l|}
\hline \multicolumn{1}{|c|}{ Theme } & \multicolumn{1}{|c|}{ Activities } & \multicolumn{1}{|c|}{ Web Tools } \\
\hline $1^{\text {st }}$ Meeting : Introduction & Course Introduction & Messenger Forum \\
\hline $2^{\text {nd }}$ Meeting : Creating Email & $\begin{array}{l}\text { How to create an email } \\
\text { Sending document through } \\
\text { Email }\end{array}$ & $\begin{array}{l}\text { Google } \\
\text { Google }\end{array}$ \\
\hline $\begin{array}{l}3^{\text {rd }} \text { Meeting : translation file or } \\
\text { document }\end{array}$ & $\begin{array}{l}\text { Using Google Translate } \\
\text { Using Google Assistance }\end{array}$ & $\begin{array}{l}\text { Google } \\
\text { Google Assistance }\end{array}$ \\
\hline $\begin{array}{l}4^{\text {th }} \text { Meeting : Widen your } \\
\text { search and idea/ resources }\end{array}$ & $\begin{array}{l}\text { Searching the Labeling in the } \\
\text { food, drink and medicine } \\
\text { product }\end{array}$ & Google/ messenger \\
\hline $\begin{array}{l}5^{\text {th }} \text { Meeting: Widen your } \\
\text { search and idea/ resources }\end{array}$ & $\begin{array}{l}\text { Searching kinds of procedure } \\
\text { text }\end{array}$ & Google/messenger \\
\hline $\begin{array}{l}6^{\text {th }} \text { Meeting : Making Video } \\
\text { editing }\end{array}$ & $\begin{array}{l}\text { Making an editing video of } \\
\text { their project when practicing } \\
\text { on one of tittle in procedure } \\
\text { text }\end{array}$ & $\begin{array}{l}\text { Video editing } \\
\text { application }\end{array}$ \\
\hline $\begin{array}{l}7^{\text {th }} \text { Meeting }: \\
\text { Presentation in Power Point }\end{array}$ & $\begin{array}{l}\text { Making power point slide } \\
\text { about their procedure text } \\
\text { project }\end{array}$ & Power Point \\
\hline $\begin{array}{l}8^{\text {th }} \text { Meeting: Creating Design } \\
\text { with Canva }\end{array}$ & $\begin{array}{l}\text { Creating Advertisement } \\
\text { Creating Class Schedule }\end{array}$ & $\begin{array}{l}\text { Google; visiting } \\
\text { canva.com }\end{array}$ \\
\hline
\end{tabular}

Table 1: The class schedule

Technology introduced to the students in this EFL classroom through its integration in the class materials; learning resources, and assignments as explained in the next subtopics: 


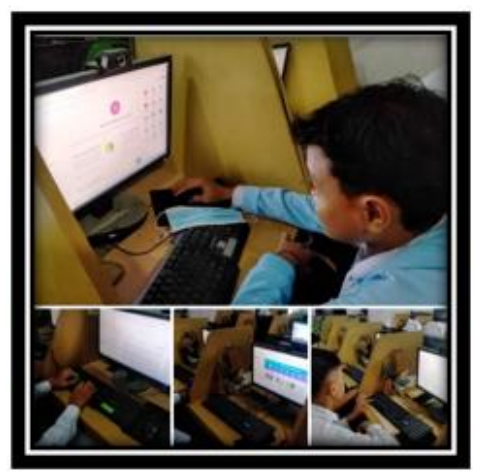

Creating an email

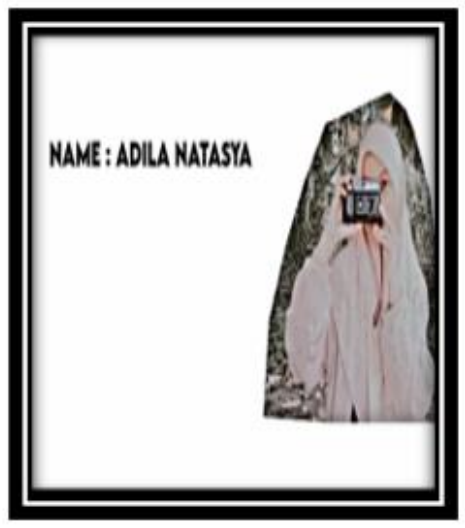

Creating video editing

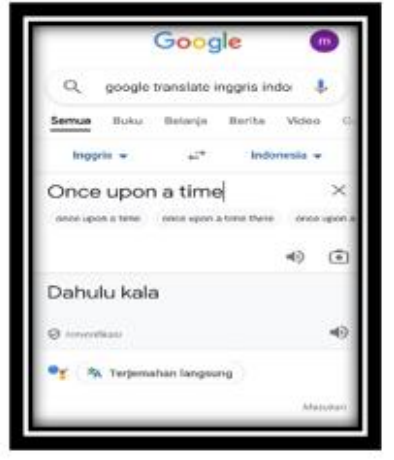

Google Translate

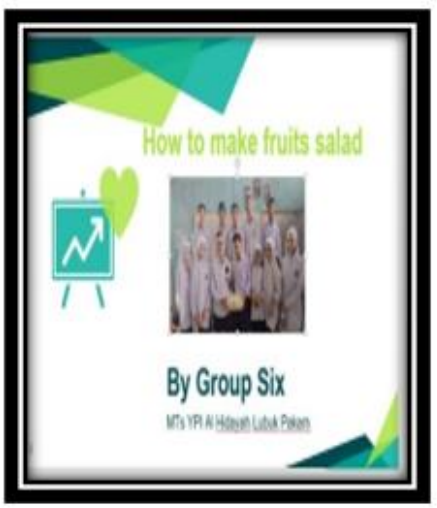

Power Point

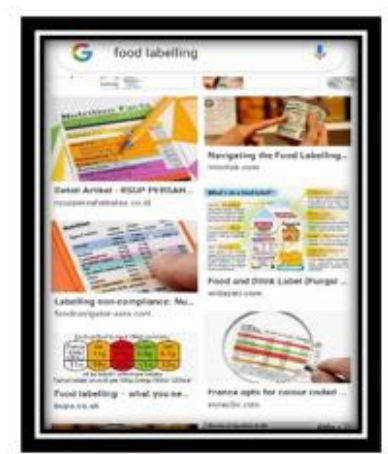

Searching food labelling in Google

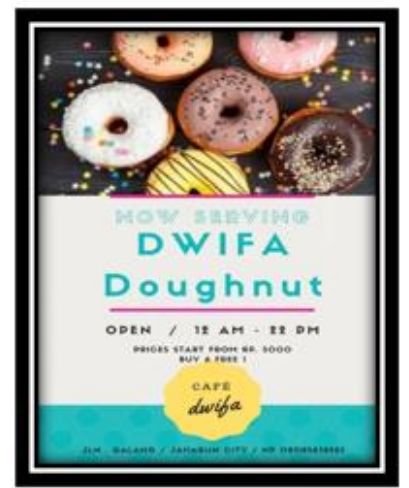

Figure 1. Some artefacts of students' projects in EFL Classroom which is integrated with Technology

\subsubsection{Creating Email}

Having an email becomes an important thing to the students before the course was started, especially when the teacher wanted to integrate the EFL classroom with web-based application. To familiarize the students in following the instructions the teacher used LCD projector. The students were following the teacher's instructions step by step. For the class assignment, the email accounts already made were asked by the teacher to send in their messenger group. The email addresses were later used to receive and send the materials and instructions about the students' projects from and to the teacher's email.

\subsubsection{Designing Advertisement in Canva}

The using of Canva in EFL classroom was to bring out the students' creativity in designing their own advertisements. This activity helped the students to understand the meaning, kinds and the function of advertisement. The students were free to choose their own advertisement theme for their projects, the teacher just instructed them to visit https://www.canva.com/, then explained the way to log in to canva and the steps in making project in canva. Canva was chosen by the teacher as one of web-based tool because it was connected with their lesson about labeling on food, drinks and medicine in grade 9. The project that had been done by them was asked to send to the messenger group to get easy 
for the teacher to check them. Then the teacher asked the students to give comment or suggestion to their friends' advertisements.

\subsubsection{Power Point}

Microsoft PowerPoint is one of non-web-based tool used in this course. It was used to encourage the students make their presentation more interesting. They could use different power point templates that the teacher shared or they individually downloaded from the internet. Later, they used the chosen templates to type their English presentation on. After that the teacher asked them to present their presentation. This activity was aimed to help them develop their speaking skills.

\subsubsection{Google Search}

Google Search as web-based tool was the most used application not only in the classroom but also out of classroom activities. In the classroom activities the students used their own smartphones, but, if in the computer laboratory, they might use the computer. They mostly used Google to search any information needed which should be related to their lessons.

\subsubsection{Google Translate}

Google translate is really helpful in EFL classroom, because it can be accessed by smartphone. The students used Google Translate to help them understand English texts by translating the dictions they were not familiar with into Indonesian. They also used it to translate some texts from Indonesian into English, particularly when they needed to complete their work but did not know how to pour their ideas in the target language.

\subsection{Students' Perception of Technology Integration in the EFL Classroom}

The second research question explored the students' perceptions related to the implementation of ICT tools in EFL Classroom during the course program. The data from close- and open-ended questionnaire were as the main source to answer this particular question. In the questionnaire, the participants were asked about the ICT tools and their understanding about ICT in the EFL classroom activities. Most of them mentioned that they could easily familiarize themselves with ICT tools used in the classroom because of the teacher's way in explaining the topic and her choice of presentation aid.

Bu guru menjelaskannya pelan-pelan sambil menunjukkan gambarnya di Power Point, makanya saya bisa paham walaupun saya tidak mencoba langsung [Translation: the female teacher explained (the lesson) slowly so I could understand it well although I didn't try it directly] - Excerpt 1

As seen in Excerpt 1, the participant mentioned that the teacher used the LCD projector to present the material that was already prepared in Power Point to support the presentation in the classroom. So, it was quite easy for her to follow the teacher's instructions. She also explained that her understandings of the ICT tools integrated in the teaching learning process was due to the teacher's way in introducing the concept. In this case, the teacher started the course from the basic one, such as how to operate the computer and explained the function of computer hardware in a precise pace that suited the students' need and comprehension. 
Other students also share similar opinions emphasizing the teacher's instructional technique as the factor that influences the success of technology integration in the class, which include " The teacher is proficient in using ICT tools," "the teacher always accompanies during the practice," and "the teacher is always responsive when I ask a question."

Another question in the open-ended questionnaire was related to the impact and benefits that the students gained from this integration of technology in the classroom. Many of the students stated that the skills in using technology which was integrated in their learning helped develop their creativity as seen in the following excerpt.

Menurut saya latihan menggunakan Canva yang paling menarik dan bermanfaat karena saya bisa berkreasi semaksimal mungkin mendisain sendiri flyer sesuai kemauan saya. Dan hasilnya ternyata luar biasa...saya tidak mengira akan sekeren iu [Translation: I think the practice in using Canva is really interesting and beneficial because I can be as creative as possible in designing the flyer as I want it. And the result turns out to be so awesome. Excerpt 2

As explained in the first findings, the activities involving web applications that the teacher introduced to the students include creating email, sending the project through email, using Google Translate to translate the document, making a project report in power point, making video editing, creating an advertisement in Canva, and submitting the projects in messenger group. In excerpt 2, the participant found that doing these tasks, particularly the one utilizing Canva helped his creativity to shine.

From the data related to the students' perception, it might be conclusive to say that integrating technology in the EFL classroom brings positive impact on the students' attitude towards English learning. Similar finding was mentioned by Amin and Sundari (2020) who found the use of technology in language learning showed positive impact. Singsay (2020) also revealed similar findings emphasizing the students' positive attitude and perceptions after the utilization of technology in second language learning.

In terms of the relationship between ICT integration with learning interest, most of the participants agreed that integrating technology in the teaching learning process develops their interest in learning English. As seen in Figure 2,65\% of the participants strongly agree that they have high interest in learning English by using technology, 31\% agree, and only 3,4 $\%$ disagree.

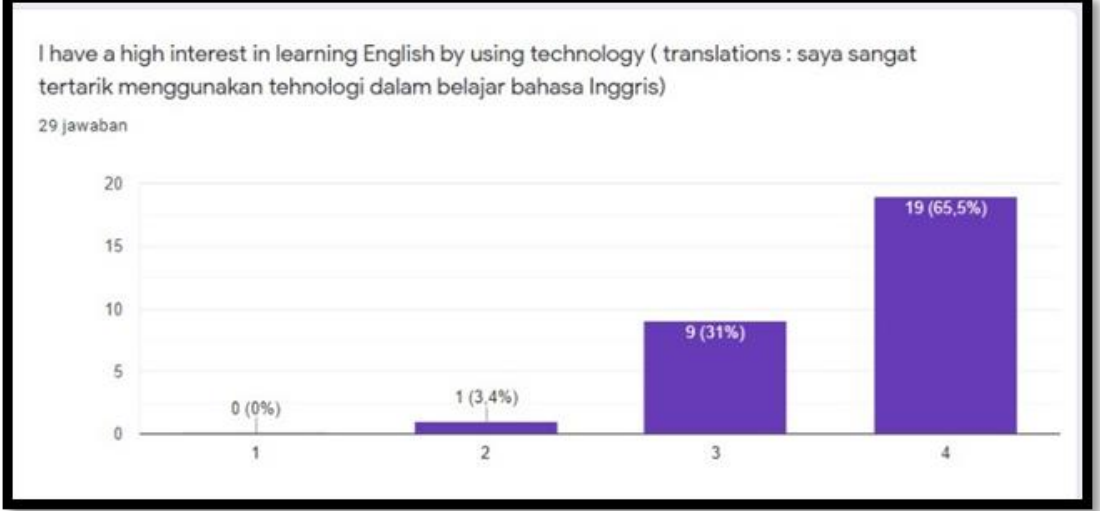

1. Strongly disagree 2. Disagree 3 . Agree 4 . Strongly agree

Figure 2. Students' interest in learning English with technology integration 
Meanwhile, in Figure 3, we can clearly see the participants' commitment to continue learning English by using technology. $53.5 \%$ of the students strongly agree that they have high commitment to continue learning English by using technology, 40\% agree and 6,7 \% disagree.

Lie et al., (2015) stated that adolescent learners significantly have higher interest learning through technology although they have different opportunities especially nowadays it is easier for them to access the technology from home through mobile phone.

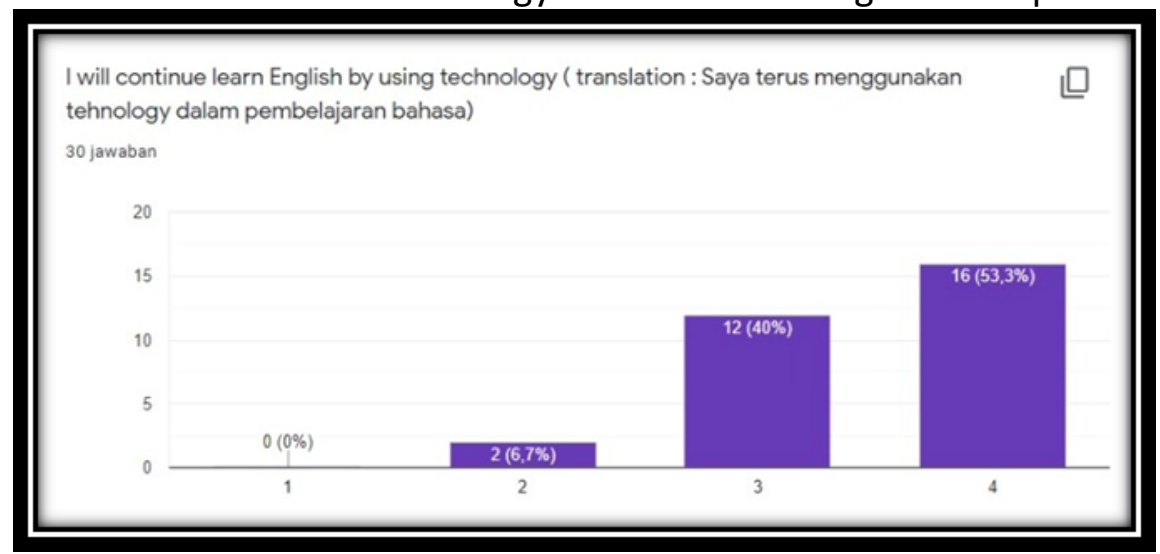

Figure 3. Students' commitment to learn English by using technology

All in all, the findings show that the activities which integrate technology in the EFL classroom make the students familiar with computer and internet access. This activity was taught step by step to them under the teacher's supervision. The students did not seem to face fundamental problems in doing the activities, except the issue with time frame in comprehending the instruction. They sometimes were left behind in following the teacher's instructions but finally could follow the course. Integrating technology in the EFL Classroom kept the students more active in performing task although for some students, some applications were quite new and unfamiliar. All of the students' projects were posted by the teacher in the school FB group which was followed by 1.825 group members to promote school and students' activities. One of the extraordinary changes through these activities that can be seen here, they become more disciplined to follow the class activity, directly without the teacher's instruction. They initiatively stayed in computer laboratory and sat in front of their computer and sometimes forgot that it was their recess time already.

\section{Conclusion}

The important trick in integrating technology into EFL Classroom is by making sure that the teacher already has the skills needed to teach it. The school's facilities such as computer laboratory, internet access, students' smartphones and projector also become the crucial factors that the school should have as they will ensure its affordability to the students so they could become familiar with computer system. The EFL teacher should also arrange the course design before the class started to ensure the learning goals be achieved. The different abilities of the students in using computer and other applications forced the teacher to be more patient and prepare more time to accompany them in learning, which eventually will help make them more confident.

\section{References}

Al-Munawwarah, S. F. (2014). Teachers' Perceptions on the Use of Ict in Indonesian Efl 
Learning Context. English Review: Journal of English Education, 3(1).

Alfred, M. V. (2003). Sociocultural contexts and learning: Anglophone Caribbean immigrant women in U.S. postsecondary education. Adult Education Quarterly, 53(4). https://doi.org/10.1177/0741713603254028

Amin, F. M., \& Sundari, H. (2020). Efl students' preferences on digital platforms during emergency remote teaching: Video conference, Ims, or messenger application? Studies in English Language and Education, 7(2). https://doi.org/10.24815/siele.v7i2.16929

Azmi, N. (2017). The Benefits of Using ICT in the EFL Classroom: From Perceived Utility to Potential Challenges. Journal of Educational and Social Research, 7(1). https://doi.org/10.5901/jesr.2017.v7n1p111

Backfisch, I., Lachner, A., Stürmer, K., \& Scheiter, K. (2021). Variability of teachers' technology integration in the classroom: A matter of utility! Computers and Education, 166. https://doi.org/10.1016/j.compedu.2021.104159

Bahous, R., Bacha, N., \& Nabhani, M. (2011). Motivating Students in the EFL Classroom: A Case Study of Perspectives. English Language Teaching, 4(3). https://doi.org/10.5539/elt.v4n3p33

Chen, L. H. (2010). Web-based learning programs: Use by learners with various cognitive styles. Computers and Education, 54(4). https://doi.org/10.1016/j.compedu.2009.10.008

Chen, Y. L., \& Hsu, C. C. (2020). Self-regulated mobile game-based English learning in a virtual reality environment. Computers and Education, 154(October 2019), 103910. https://doi.org/10.1016/j.compedu.2020.103910

Cook, D. A., Garside, S., Levinson, A. J., Dupras, D. M., \& Montori, V. M. (2010). What do we mean by web-based learning? A systematic review of the variability of interventions. In Medical Education (Vol. 44, Issue 8). https://doi.org/10.1111/j.13652923.2010.03723.x

Fadel, Charles, Bialik, Maya, Trilling, B. (2015). Four-Dimensional Education. Center for Curriculoum Redesign.

Junaidia, J., Hamuddinb, B., Simangunsongc, W., Rahmand, F., \& Derine, T. (2020). ICT usage in teaching english in pekanbaru: Exploring junior high school teachers' problems. International Journal of Innovation, Creativity and Change, 12(4).

Mariani, P., Marletta, A., \& Zenga, M. (2019). What do employers look for when hiring new graduates? Answers from the electus survey. Springer Proceedings in Mathematics and Statistics, 288. https://doi.org/10.1007/978-3-030-21158-5_27

Nim Park, C., \& Son, J.-B. (2009). Implementing Computer-Assisted Language Learning in the EFL Classroom: Teachers' Perceptions and Perspectives. International Journal of Pedagogies and Learning, 5(2). https://doi.org/10.5172/ijpl.5.2.80

Pelgrum, W. J., Janssen, R., I.A.M, \& Plomp, T. (1993). Schools, Teachers, Students and Computers: a Cross-National Perspective. In Books.

Singay. (2020). Flipped learning in English as a second language classroom: Bhutanese students' perceptions and attitudes of flipped learning approach in learning grammar. Indonesian Journal of Applied Linguistics, 9(3). https://doi.org/10.17509/ijal.v9i3.23217

Supriadi, Y., Nisa, A. A., \& Wulandari, S. (2020). English Teachers' Beliefs on Technology Enhanced Language Learning: A Rush Paradigmatic Shift during Covid-19 Pandemic. Pancaran Pendidikan, 9(2). https://doi.org/10.25037/pancaran.v9i2.290 
Tokareva, E. A., Smirnova, Y. V., \& Orchakova, L. G. (2019). Innovation and communication technologies: Analysis of the effectiveness of their use and implementation in higher education. Education and Information Technologies, 24(5). https://doi.org/10.1007/s10639-019-09922-2

Yang, S. C., \& Chen, Y.-J. (2007). Technology-enhanced language learning: A case study Computers in Human Behavior. Computers in Human Behavior, 23.

Yin, R. K. (2013). Applications of case study research. Applied Social Research Methods Series, 34. https://doi.org/10.1097/FCH.0b013e31822dda9e 